4 indicate a HOMO-LUMO separation of $1.25 \mathrm{eV}$ (slightly larger than that in 2), so that at the short $\mathrm{Co}-\mathrm{Co}$ separation a singlet ground state seems more likely than a triplet ground state. In 6, the four hydride ligands interact strongly with one of the $\mathrm{Co}-\mathrm{Co} \delta$ and both $\mathrm{Co}-\mathrm{Co} \pi$ orbitals, leading to significant destabilization of these metal-based orbitals, much as we saw for $\left.[\mathrm{CpReH})_{2}(\mu-\mathrm{H})_{4}\right] .^{[15]}$ As a result of these interactions, the HOMO's of 6 are the half-filled, doubly degenerate Co-Co $\pi^{*}$ orbitals [Figure 1 (right)], and the molecule is expected to possess a triplet ground state.

Complex 6 has strong precedent in the literature. An analogous Group 8 complex, $\left[\left(\mathrm{Cp}^{*} \mathrm{Ru}\right)_{2}(\mu-\mathrm{H})_{4}\right](9)$, which has two fewer valence electrons than 6 and is diamagnetic, possesses a $R u-R u$ bond length of $2.463 \AA$ consistent with its formulation as a hydride-supported metal-metal triple bond. ${ }^{[16]}$ In addition, we have recently demonstrated that $\left[\mathrm{Cp}_{2}^{*} \operatorname{Re}_{2}(\mathrm{CO})_{4}\right](10)$, which contains a $\mathrm{Re}-\mathrm{Re}$ double bond supported by two semibridging carbonyls, reacts with $\mathrm{H}_{2}$ at $-80^{\circ} \mathrm{C}$ to yield $\left[\mathrm{Cp}_{2}^{*} \operatorname{Re}_{2}(\mathrm{CO})_{4}(\mu-\mathrm{H})_{2}\right] .^{[3]}$ Compound 10 is more sterically congested than $\left[\mathrm{Cp}_{2}^{*} \mathrm{Co}_{2}\right]$, suggesting that the latter would also undergo facile addition of hydrogen (an expected by-product of the reaction of Co atoms with $\mathrm{Cp} * \mathrm{H}$ ) to the Co-Co bond.

In summary, we believe that the electronic structure of 2 together with the reactivity exhibited by 1 casts some doubt on whether the latter is truly $\left[\mathrm{Cp}_{2}^{*} \mathrm{Co}_{2}\right]$, and feel that there may be additional hydride ligands present in the observed structure. The presence of one, three, or four bridging hydride ligands could explain the observed magnetic behavior of 1 , and compounds with such supporting ligands would be less reactive than one containing an unsupported $\mathrm{Co}-\mathrm{Co}$ double bond. We are currently undertaking higher level electronic structure calculations on compounds 2-6, and we hope these comments stimulate further experimental studies of compound 1.

Received: November 8, 1991 [Z 5010 IE] German version: Angew. Chem. 1992, 104, 464

CAS Registry numbers:

2. 139495-49-1; 3. 139495-50-4;4, 139495-51-5; 5, 139495-52-6; 6, 139495-53-7.

[1] J. J. Schneider, R. Goddard, S. Werner, C. Krüger, Angew. Chem. 1991, 103, 1145; Angew. Chem. Int. Ed. Engl. 1991, 30, 1124.

[2] R. Toreki, R. R. Schrock, M. G. Vale, J. Am. Chem. Soc. 1991, 113, 3610

[3] C. P. Casey, H. Sakaba, P. N. Hazin, D. R. Powell, J. Am. Chem. Soc. $1991,113,8165$.

[4] J. P. Blaha, B. E. Bursten, J. C. Dewan, R. B. Frankel, C. L. Randolph, B. A. Wilson, M. S. Wrighton, J. Am. Chem. Soc. 1985, 107, 4561.

[5] Computational details: Molecular orbital calculations employed the Fenske-Hall method (M. B. Hall, R. F. Fenske, Inorg. Chem. 1972, 11, 768; B. E. Bursten, Pure \& Appl. Chem. 1991, 63, 839) with a Slater-type orbital (STO) basis derived from numerical atomic calculations [B. E. Bursten, J. R. Jensen, R. F. Fenske, J. Chem. Phys. 1978, 68, 3320. The Co $4 s$ and $4 p$ orbital exponents were both set equal to 2.00 . The molecular orbitals were analyzed by Mulliken populations and fragment analysis [D. L. Lichtenberger and R. F. Fenske, J. Chem. Phys. 1976, 64, 4247]. The metric parameters of 2 were taken from the crystal structure of 1 , and the molecule was idealized to $D_{5}$ symmetry. The assumed geometries of 3-6 were identical to that of 2 except for the addition of symmetrically bridging hydride ligands at a $\mathrm{Co}-\mathrm{H}$ distance of $1.79 \AA$

[6] T. A. Albright, J. K. Burdett, M. H. Whangbo, Orbital Interactions in Chemistry, Wiley, New York, 1985, Chapter 20.

[7] D. L. Lichtenberger, A. S. Copenhaver, J. L. Hubbard, Polyhedron 1990 9. 1783 .

[8] S. D. Loren, B. K. Campion, R. H. Heyn, T. D. Tilley, B. E. Bursten, K. W. Luth, J. Am. Chem. Soc. 1989, 111, 4712.

[9] We cannot determine state energies from Fenske-Hall MO calculations. However, the HOMO-LUMO splitting is an upper bound to the energy difference between the singlet ground state and the lowest triplet excited state

[10] J. Wachter, Angew. Chem. 1991, 103, 1140; Angew. Chem. Int. Ed. Engl. $1991,30,1120$.

[11] a) W. I. Bailey, D. M. Collins, F. A. Cotton, J. C. Baldwin, W. C. Kaska, J. Organomet. Chem. 1979, 165, 373; b) L. M. Cirjak, R. E. Ginsburg, L. F. Dahl, Inorg. Chem. 1982, 21, 940.

[12] L. R. Byers, L. F. Dahl, Inorg. Chem. 1980, 19, 277

[13] The mass spectrum of 1 could not be obtained due to decomposition. [1] and combustion analysis can not unambiguously rule out bridging hydride ligands, as shown by the theoretical elemental analyses of $\left[\mathrm{Cp}_{2}^{*} \mathrm{Co}_{2}\right]$ $\left[\mathrm{Cp}_{2}^{*} \mathrm{CoH}_{2}\right]$ and $\left[\mathrm{Cp}_{2}^{*} \mathrm{Co}_{2} \mathrm{H}_{4}\right]$ :

$\left[\mathrm{Cp}_{2}^{*} \mathrm{Co}_{2}\right]$ : $\mathrm{Co} 30.35, \mathrm{C} 61.86, \mathrm{H} 7.79 \%$;

$\left[\mathrm{Cp}_{2}^{*} \mathrm{Co}_{2} \mathrm{H}_{2}\right]$ : Co $30.19, \mathrm{C} 61.54, \mathrm{H} 8.26 \%$;

$\left[\mathrm{Cp}_{2}^{*} \mathrm{Co}_{2} \mathrm{H}_{4}\right]: \mathrm{Co} 30.04, \mathrm{C} 61.22, \mathrm{H} 8.73 \%$

$\left[\mathrm{Cp}_{3}^{*} \mathrm{CO}_{2}\right]: \mathrm{Co} 22.51, \mathrm{C} 68.82, \mathrm{H} 8.66 \%$.

The last compound is included because 1 is cocrystallized with $\left[\mathrm{Cp}_{3}^{*} \mathrm{Co}_{2}\right]$, and reference is made to repeated recrystallizations in order to provide analytically pure 1 . Chronically high hydrogen analyses might be interpreted as $\left[\mathrm{Cp}_{3}^{*} \mathrm{Co}_{2}\right]$ in $\left[\mathrm{Cp}_{2}^{*} \mathrm{Co}_{2}\right]$, but the actual values for the analytically pure sample were not stated in [1].

[14] U. Koelle, B. Fuss, M. Belting, E. Raabe, Organometallics 1986, 5, 980.

[15] B. E. Bursten, R. H. Cayton, Organometallics 1988, 7, 1349.

[16] a) H. Suzuki, H. Omori, H. L. Lee, Y. Oshida, Y. Moro-oka, Organometallics 1988, 7, 2243; b) R. E. Marsh, ibid. 1989, 8, 1583.

\title{
1,2,4-Cyclohexatriene, an Isobenzene, and Bicyclo[4.4.0]deca-1,3,5,7,8-pentaene, an Isonaphthalene: Generation and Trapping Reactions**
}

\section{By Manfred Christl,* Martin Braun, and Germar Müller}

After Miller and Shi ${ }^{[1]}$ had generated the isomer 1 of dimethylnaphthalene by $\beta$ elimination of $\mathrm{HBr}$ and had trapped it with potassium tert-butoxide as well as diphenylisobenzofuran, we asked ourselves whether the isonaphthalene $\mathbf{2}$ and the isobenzene 3 could also be prepared and subjected to trapping reactions. Two further isobenzenes, namely $1,2,3-$ cyclohexatriene and cyclohex-1-en-3-yne, were recently generated and intercepted. ${ }^{[2]}$

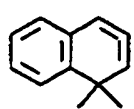

1

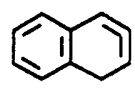

2

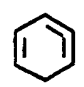

3

In connection with our work ${ }^{[3]}$ concerning 1,2-cyclohexadiene and its derivatives, ${ }^{[4]}$ we wanted to liberate 2 and 3 using the Doering-Moore-Skattebøl method. At first, the dibromocyclopropanes 13 and 14 were considered as unsuitable starting materials, since the addition of dibromocarbene, generated from bromoform and a base, to indene and cyclopentadiene only yields 2 -bromonaphthalene ${ }^{[5]}$ and bromobenzene, respectively, because of the rapid rearrangement of 13 and 14.

Therefore, as previously for a precursor of 1-oxacyclohexa-2,3-diene, ${ }^{[6]}$ we used the high energy of the $\mathrm{C}-\mathrm{F}$ bond and added bromofluorocarbene $\left(\mathrm{CHBr}_{2} \mathrm{~F}, 50 \% \mathrm{NaOH}\right.$, $\mathrm{PhCH}_{2} \mathrm{NEt}_{3} \mathrm{Cl}, \mathrm{CH}_{2} \mathrm{Cl}_{2}$, ice bath) to indene and cyclopentadiene. We obtained $6^{[7.8]}$ and $10^{[7]}$ in 16 and $20 \%$ yields,

[*] Prof. Dr. M. Christl, Dr. M. Braun, Dipl.-Chem. G. Müller Institut für Organische Chemie der Universität Am Hubland, D-W-8700 Würzburg (FRG)

[**] Cycloallenes, Part 8 . This work was supported by the Deutsche Forschungsgemeinschaft and the Fonds der Chemischen Industrie. We thank Prof. Dr. L. Skattebel, Oslo, for valuable suggestions and Prof. Dr. R. Janoschek, Graz, for the theoretical study of the isobenzene 3 (see following communication [11]).--Part 7: H. Jelinek-Fink, M. Christl, E.-M Peters, K. Peters, H. G. von Schnering, Chem. Ber. 1991, 124, 2569-2575. 
respectively. Only upon heating, the compounds $6\left(130^{\circ} \mathrm{C}\right.$, $3.5 \mathrm{~h})$ and $10\left(70^{\circ} \mathrm{C}, 2 \mathrm{~h}\right)$ decompose to give 2-bromonaphthalene and bromobenzene, respectively.

As hoped, methyllithium causes the $\mathrm{Br}-\mathrm{Li}$ exchange in 6 and 10 , followed by the loss of LiF. This leads, with ring expansion, to the cyclic allenes 2 and 3 , respectively, as the products of trapping reactions suggest.

Thus, a $14: 1$ mixture of the $[2+2]$ cycloadducts $4^{[7]}$ and $5^{[7]}$ of the isonaphthalene 2 was formed by the reaction of 6 in styrene with $\mathrm{MeLi}$ in ether at $-25^{\circ} \mathrm{C}$ in $63 \%$ yield. Analogous products were obtained with $\alpha$-methylstyrene. The use of butadiene as the trapping reagent afforded a $4: 2: 1$ mixture of the $[2+2]$ cycloadduct $7,\left[{ }^{[7]}\right.$ and the $[4+2]$ cycloadducts $8^{[7]}$ and $9^{[7]}$ in $27 \%$ yield. In the case of 2,3 -dimethylbutadiene, the amount of the $[2+2]$ cycloadduct was significantly larger than that of the $[4+2]$ cycloadducts.

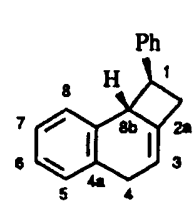<smiles>C[14C]([14CH])=[18O]</smiles><smiles>C1=C2C[C@H](c3ccccc3)[C@H]2Cc2ccccc21</smiles>

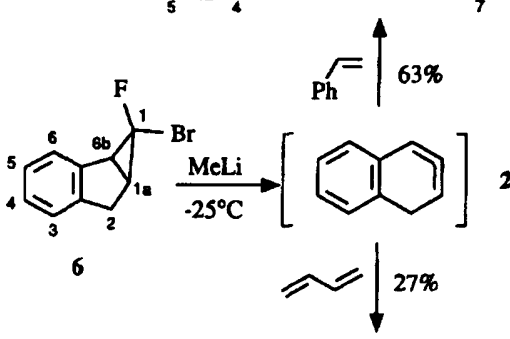

7<smiles>C=C[C@H]1CC2=CCc3ccccc3[C@H]21</smiles><smiles>C1=CCC2C(=C1)Cc1ccccc12</smiles><smiles>C1=CCC2Cc3ccccc3C=C2C1</smiles>

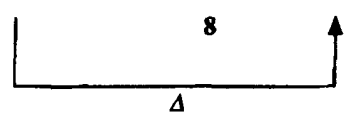

If $\mathbf{1 0}$ is allowed to react with $\mathrm{MeLi}$ in the presence of styrene, then the $[2+2]$ cycloadduct $11^{[7]}$ of 3 and probably its diastereomer are obtained as a 19:1 mixture in $65 \%$ yield. The trapping reaction of 3 with $\alpha$-methylstyrene proceeded analogously.<smiles>FC1(Br)C2C=CC(C2)C1C(CCc1ccccc1)CCc1ccccc1</smiles>

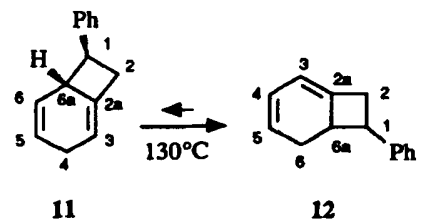

We then investigated whether the dibromocarbene adducts of indene and cyclopentadiene, namely 13 and 14 , re-

spectively, were also stable enough for preparative purposes. Produced from indene and cyclopentadiene, respectively, and tetrabromomethane in ether with $\mathrm{MeLi}{ }^{[9]}$ at $-60^{\circ} \mathrm{C}$, they are actually stable in solution up to $0^{\circ} \mathrm{C}$ as proved by the ${ }^{1} \mathrm{H}$ NMR spectra. We have used these findings to synthesize the cycloadducts of 2 and 3 in one-pot reactions.

Treatment of 13 , prepared at $-60^{\circ} \mathrm{C}$, with $\mathrm{MeLi}$ in the presence of styrene at $-30^{\circ} \mathrm{C}$ furnishes the same mixture of 4 and 5 as from the use of 6 . With butadiene instead of styrene, 7-9 were again formed. The yields based on indene were, with 40 and $24 \%$, respectively, considerably higher than from the method via 6 (10 to $4 \%$, respectively).

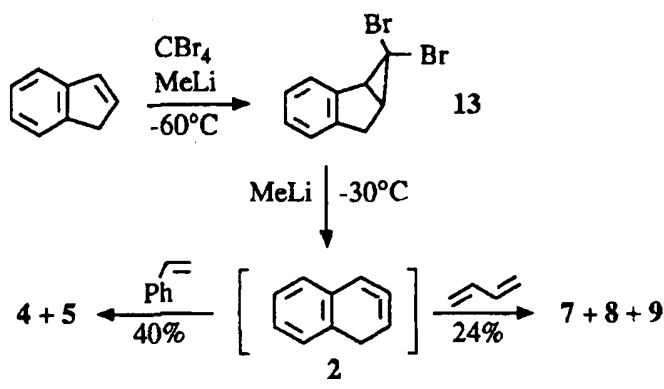

The cycloadducts 11 (49\% compared with $13 \%$ via 10 ), $17^{[7]}(14 \%)$ and $18^{[7]}(8 \%), 15^{[7]}(5 \%)$, and $16^{[7]}(5 \%)$, were formed analogously from cyclopentadiene, tetrabromomethane, $\mathrm{MeLi}$, and the trapping reagents styrene and cyclopentadiene (see Experimental Procedure) as well as $(E)-\beta$ methylstyrene and furan, respectively. The 1,4-cyclohexadiene subunits of these compounds and their configurations are proved unequivocally by NMR spectroscopy (cf. Table 1)

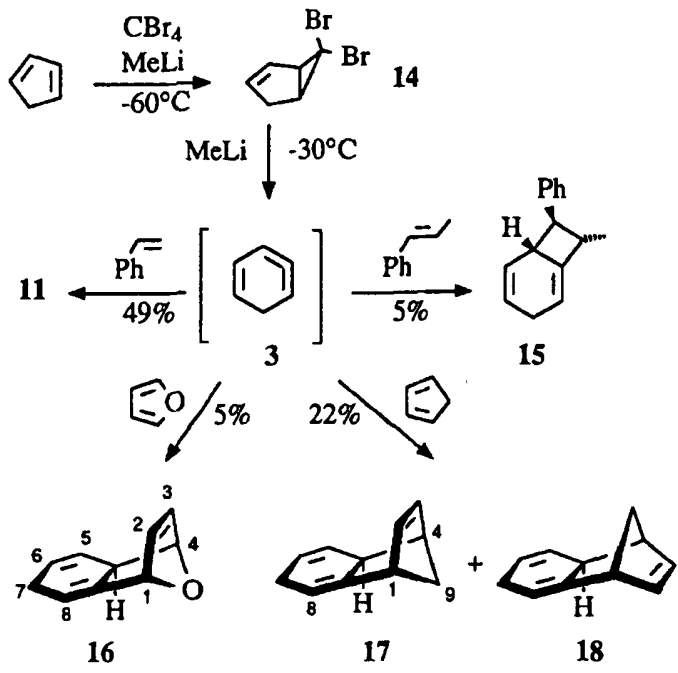

Noteworthy are the reactivities of the different allene $\pi$ bonds in 2 and 3 . The [4+2]cycloaddition of 2 with butadiene appears to lead, with little selectivity, to a $2: 1$ mixture of the tetrahydrophenanthrene 8 and the tetrahydroanthracene 9. Due to the readily occurring thermal rearrangement of the $[2+2]$ cycloadduct 7 , formed at the same time, into 8 and 9 in the ratio $2: 1$, this result must be confirmed by further investigations. The exclusive participation of the conjugated allene $\pi$ bond in the $[4+2]$ cycloadditions of 3 results in the 
formation of 16-18. We explain this by the more favorable frontier orbital energies in comparison to those of the nonconjugated allene $\pi$ bond. This is based on the assumption of a one-step mechanism in the sense of the Diels-Alder reaction. In the $[2+2]$ cycloadditions those allene $\pi$ bonds react which are conjugated with the benzene unit in 2 and the ethylene unit in 3 , respectively. On the basis of previous

Table 1. Selected physical data of $4-18 ;{ }^{1} \mathrm{H}$ NMR (200 or $400 \mathrm{MHz}$ ) and ${ }^{13} \mathrm{C}$ NMR ( 50 or $100 \mathrm{MHz}$ ) spectra measured in $\mathrm{CDCl}_{3}$ if not stated otherwise.

4: $\mathrm{Mp}=45-47^{\circ} \mathrm{C}$. ' ${ }^{\mathrm{H}} \mathrm{NMR}\left(\mathrm{C}_{6} \mathrm{D}_{6}\right): \delta=2.87$ (m, 2H; H2), 3.09 (ddd, $J(4,4)=18.8, J(3,4)=6.3, J(4,8 b)=2.3 \mathrm{~Hz}, 1 \mathrm{H} ; \mathrm{H} 4), 3.25(\mathrm{dm}, J(3,4)=$ $2.9 \mathrm{~Hz}, 1 \mathrm{H} ; \mathrm{H} 4), 3.27$ (q, mean $J(1,2)=J(1,8 \mathrm{~b})=8.3 \mathrm{~Hz} ; \mathrm{H1}), 3.95(\mathrm{~m} ; \mathrm{H} 8 \mathrm{~b})$ $5.58(\mathrm{ddq}$, mean $J(2,3)=J(3,8 \mathrm{~b})=1.9 \mathrm{~Hz} ; \mathrm{H3}), 6.90-7.90(\mathrm{~m}, 9 \mathrm{H} ; \mathrm{H}$-arene) ${ }^{13} \mathrm{C}$ NMR: $\delta=30.6(\mathrm{t} ; \mathrm{C} 4), 38.1(\mathrm{t} ; \mathrm{C} 2), 46.9,51.7$ (each d; C1,8b), 113.7 (d) C3), 125.4, 126.0, 126.1, 126.4, 128.2 (each d; C5,6,7,8, p-C), 126.9 (d; o-C), $128.6(\mathrm{~d} ; m-\mathrm{C}), 136.4,139.1,139.4$ (each s; C2a,4a,8a), 144.2 (s; ipso-C)

$5:{ }^{1} \mathrm{H}$ NMR: $\delta=2.77-3.34(\mathrm{~m} ; 6 \mathrm{H}), 6.22$ (t, line width $\left.2.0 \mathrm{~Hz} ; \mathrm{H} 3\right), 6.96-7.38$ (m; $9 \mathrm{H}$-arene); ${ }^{13} \mathrm{C}$ NMR: $\delta=34.7(\mathrm{t} ; \mathrm{C} 8), 37.7(\mathrm{t} ; \mathrm{C} 2), 45.08,45.13$ (each d C1,8a), 115.8 (d; C3), 125.7, 125.8, 126.2, 126.7, 128.2 (each d; C4,5,6,7, p-C) 126.5 (d; $o$-C), 128.4 (d; $m-\mathrm{C}), 134.3,135.4$ (each s; C3a,7a), 141.8 (s; C2a), 144.1 (s; ipso-C)

6: $\mathrm{Mp}=71-72^{\circ} \mathrm{C} .{ }^{3} \mathrm{H}$ NMR: $\delta=2.51(\mathrm{~m}, 1 \mathrm{H}), 3.18(\mathrm{~m}, 3 \mathrm{H}), 7.08-7.22(\mathrm{~m}$ $3 \mathrm{H}), 7.32(\mathrm{~m}, 1 \mathrm{H}) ;{ }^{13} \mathrm{C}$ NMR: $\delta=32.2(\mathrm{td}, J(\mathrm{C}, \mathrm{F})=3.5 \mathrm{~Hz} ; \mathrm{C} 2), 34.0(\mathrm{dd}$, $J(\mathrm{C}, \mathrm{F})=12.6 \mathrm{~Hz} ; \mathrm{C} 1 \mathrm{a}), 41.3(\mathrm{dd}, J(\mathrm{C}, \mathrm{F})=12.1 \mathrm{~Hz} ; \mathrm{C} 6 \mathrm{~b}), 82.6(\mathrm{~d}, J(\mathrm{C}, \mathrm{F})=$ $315.0 \mathrm{~Hz} ; \mathrm{C} 1$ ), 124.3, 125.2, 126.7, 127.3 (each d; C3,4,5,6), 137.0 (d, $J(\mathrm{C}, \mathrm{F})=2.5 \mathrm{~Hz}), 143.5(\mathrm{~s} ; \mathrm{C} 2 \mathrm{a}, 6 \mathrm{a})$

$7:{ }^{13} \mathrm{C} \mathrm{NMR}: \delta=30.4(\mathrm{t} ; \mathrm{C} 4), 36.0(\mathrm{t} ; \mathrm{C} 2), 45.7,49.8$ (each d; C1,8b), 113.0 (d C3), $113.8(t), 141.8$ (d) $\left(\mathrm{CH}=\mathrm{CH}_{2}\right), 125.3,126.1$ (double intensity), 128.1 (each d; C5,6.7,8), 136.3, 139.0, 139.6 (each s; C2a,4a,8a)

8: ${ }^{13} \mathrm{C}$ NMR: $\delta=29.5,34.9,36.9$ (each $\left.\mathrm{t} ; \mathrm{C} 1,4,9\right), 38.0$ (d; C4a), 116.4 (d; C10), $125.8,126.0,126.6,126.9,127.7,128.3$ (each d; $C 2,3,5,6,7,8$ ), 133.2, 134.8, 137.7 (each s; C4b,8a,10a)

9: ${ }^{13} \mathrm{C}$ NMR: $\delta=33.1,33.5,33.8$ (each t; C1,4,10), 34.3 (d; C4a), 120.7 (d; C9), 125.3, 126.32, 126.34, 126.4, 126.8, 127.5 (each d; C2,3,5,6,7,8); the signals of $\mathrm{C} 4 \mathrm{a}, 8 \mathrm{a}, 10 \mathrm{a}$ could not be located precisely because of the low intensity.

10: ' $\mathrm{H}$ NMR: $\delta=2.31$ (ddddd, $J=7.6,6.5,2.5,1.8,0.7 \mathrm{~Hz}$; H5), 2.60 (br dquin, $J=16.0,2.4 \mathrm{~Hz}, 1 \mathrm{H} ; \mathrm{H} 4), 2.66(\mathrm{dm}, 1 \mathrm{H} ; \mathrm{H4}$ ), 2.73 (dtdd, $J=7.6,2.4$, $1.0,0.4 \mathrm{~Hz} ; \mathrm{H1}), 5.64(\mathrm{dq}, J=5.6,2.1 \mathrm{~Hz}), 5.78(\mathrm{dtd}, J=5.6,2.2,0.8 \mathrm{~Hz})$ (H2.3); ${ }^{13} \mathrm{C} \mathrm{NMR}: \delta=33.3$ (td, $\left.J(\mathrm{C}, \mathrm{F})=3.0 \mathrm{~Hz} ; \mathrm{C} 4\right), 33.5$ (dd, $J(\mathrm{C}, \mathrm{F})=$ $13.3 \mathrm{~Hz}), 41.6(\mathrm{dd}, J(\mathrm{C}, \mathrm{F})=12.4 \mathrm{~Hz})(\mathrm{C} 1,5), 82.5(\mathrm{~d}, J(\mathrm{C}, \mathrm{F})=316.0 \mathrm{~Hz} ; \mathrm{C} 6)$, $124.5(\mathrm{~d} ; \mathrm{C} 3), 133.6(\mathrm{dd}, J(\mathrm{C}, \mathrm{F})=1.7 \mathrm{~Hz} ; \mathrm{C} 2)$

11: ${ }^{1} \mathrm{H}$ NMR [a]: $\delta=2.66(\mathrm{~m}, 2 \mathrm{H} ; \mathrm{H4}), 2.91$ (ddquin, $J(2,2)=12.5$, $J(1,2)=9.0, J(2,3) \approx$ mean $J(2,4) \approx J(2,6 \mathrm{a}) \approx 1.9 \mathrm{~Hz}, 1 \mathrm{H} ; \mathrm{H} 2$ ), 2.98 (ddquin $J(1,2)=7.2, J(2,3) \approx$ mean $J(2,4) \approx J(2,6 \mathrm{a}) \approx 1.4 \mathrm{~Hz}, 1 \mathrm{H} ; \mathrm{H} 2), 3.19(\approx \mathrm{q}$ $J(1,6 \mathrm{a})=8.3 \mathrm{~Hz} ; \quad \mathrm{H} 1), \quad 3.35 \quad(\approx \mathrm{qtq}, \quad$ mean $J(4,6 \mathrm{a})=8.2, \quad J(3,6 \mathrm{a}) \approx$ $J(5,6 \mathrm{a}) \approx 3.0, J(6,6 \mathrm{a})=1.8 \mathrm{~Hz} ; \mathrm{H6a}), 5.44(\mathrm{~m} ; \mathrm{H} 3), 5.83(\approx \mathrm{dqd}, J(5,6) \approx 9.4$ mean $J(4,5) \approx 3.1, J(3,5)=0.9 \mathrm{~Hz} ; \mathrm{HS}), 5.91(\mathrm{dq}$, mean $J(4,6)=1.9 \mathrm{~Hz} ; \mathrm{H6}$ ), 7.17-7.33 (m; $\left.\mathrm{C}_{6} \mathrm{H}_{5}\right) ;{ }^{13} \mathrm{C}$ NMR: $\delta=26.4(\mathrm{t} ; \mathrm{C} 4), 38.4(\mathrm{t} ; \mathrm{C} 2), 46.9(\mathrm{~d} ; \mathrm{C} 6 \mathrm{a})$ $50.6(\mathrm{~d} ; \mathrm{C} 1), 112.0(\mathrm{~d} ; \mathrm{C} 3), 126.2(\mathrm{~d}, p-\mathrm{C}), 126.6(\mathrm{~d} ; o-\mathrm{C}), 127.2,127.3$ (each $d$ C5,6), 128.4 (d; m-C), 138.5 (s; C2a), 144.0 (s; ipso-C)

12: ${ }^{1} \mathrm{H}$ NMR: $\delta=2.18(\mathrm{ddm}, J(6,6)=17.5, J(6 e n d o, 6 \mathrm{a})=14.0 \mathrm{~Hz} ;$ endo-H6), 2.40 (dddm, $J(6$ exo, $6 \mathrm{a})=9.7, J(5,6$ exo $)=6.0 \mathrm{~Hz} ;$ exo-H6), $2.90-3.06(\mathrm{~m}$ $2 \mathrm{H}), 3.08-3.30(\mathrm{~m}, 2 \mathrm{H}), 5.55-5.70(\mathrm{~m}, 2 \mathrm{H}), 5.94(\mathrm{~m}, 1 \mathrm{H}), 7.15-7.37(\mathrm{~m}$; $\left.\mathrm{C}_{6} \mathrm{H}_{5}\right) ;{ }^{13} \mathrm{C}$ NMR: $\delta=27.8$ (t; C6), 38.4 (t; C2), 43.4, 45.9 (each d; C1,6a), 123.0, 125.1, 125.9, 126.1 (each d; C3,4,5, $p-C), 126.4$ (d; $\sigma-C), 128.5$ (d; $m-C)$, 138.4 (s; C2a), 144.4 (s; ipso-C)

13: ' $\mathrm{H}$ NMR $\left(\mathrm{CDCl}_{3} /\right.$ ether $): \delta=2.57(\mathrm{br} \mathrm{t}, J(1 \mathrm{a}, 2$ exo $) \approx J(1 \mathrm{a}, 6 \mathrm{~b}) \approx 7.0 \mathrm{~Hz}$; H1a), 2.97 (br d, $J(2,2)=17.7 \mathrm{~Hz}$; endo-H2) 3.17 (dd; exo-H2), 3.26 (br d; H6b), 7.05-7.17 (m, 3 H), 7.28 (br d, $J=7.3 \mathrm{~Hz} ; 1 \mathrm{H}$ )

14: ' ${ }^{\mathrm{H}} \mathrm{HMR}\left(\mathrm{CDCl}_{3} / \mathrm{ether}\right): \delta=2.29(\mathrm{dm} ;$ endo-4-H), 2.30 (br t; H5), 2.55 (ddt, $J(4,4)=18.6, J(4 e x o, 5)=7.6, J(2,4 e x o) \approx J(3,4 e x o) \approx 2.0 \mathrm{~Hz} ;$ exo-H4), $2.73(\approx \mathrm{dt}, J(1,5)=7.2, J(1,4 \mathrm{endo})=3.0, J(1,2)=2.4 \mathrm{~Hz} ; \mathrm{H} 1), 5.58$ (dq, $J(2,3)=5.5, J(2,4$ endo $)=2.2 \mathrm{~Hz} ; \mathrm{H} 2), 5.77$ (dtd, $J(3,4$ endo $)=2.2, J(3,5)=$ $0.8 \mathrm{~Hz} ; \mathrm{H} 3$ )

15: ${ }^{13} \mathrm{C} \mathrm{NMR}: \delta=17.0\left(q ; \mathrm{CH}_{3}\right), 26.1$ (t; C 4), 47.3, 47.6 (each d; $\left.\mathrm{C} 2.6 \mathrm{a}\right), 55.6$ (d; C1), 109.7 (d; C3), 126.3 (d; $p$-C), 126.7 (d; o-C), 127.2, 127.3 (each d; C5,6), 128.4 (d; $m-\mathrm{C}$ ), 143.2, 145.0 (each s; C2a, ipso-C)

16: ${ }^{1} \mathrm{H}$ NMR $[\mathrm{a}]: \delta=2.64-2.73(\mathrm{~m}, 2 \mathrm{H} ; \mathrm{H} 7), 2.90(\mathrm{~m} ; \mathrm{H} 4 \mathrm{a}), 5.18(\mathrm{~m} ; \mathrm{H} 1), 5.19$ $(\mathrm{dm}, \quad J(4,4 \mathrm{a}) \approx 4.0 \mathrm{~Hz} ; \quad \mathrm{H4}), \quad 5.59 \quad(\mathrm{qm} ; \quad J(4 \mathrm{a}, 8) \approx$ mean $\quad J(7,8) \approx$ $3.5 \mathrm{~Hz} ; \mathrm{H} 8$ ), 5.80 (br s; H5.6), 6.09 (dd, $J(2,3)=5.7, J(3,4)=1.6 \mathrm{~Hz} ; \mathrm{H3}), 6.43$ (br dd, $J(1,2)=1.6 \mathrm{~Hz} ; \mathrm{H} 2) ;{ }^{13} \mathrm{C}$ NMR: $\delta=28.0$ (t; C7), 40.6 (d; C4a), 80.1, 80.7 (each d; C 1,4), 112.9 (d; C8), 126.7, $128.4,129.9$ (each d; C3,5,6), 136.1 (d) $\mathrm{C} 2), 141.7$ (s; C8a)
Table 1. (continued)

17: ${ }^{13} \mathrm{C}$ NMR: $\delta=28.1$ (t; C7), 41.9 (d; C4a), 45.5, 47.4 (each d; C1,4), 50.4 $(t ; C 9), 112.3$ (d; C8), 127.4, 130.3, 131.0 (each d; C3,5,6), 136.4 (d; C2), 146.2 (s; C8)

18 [a]: ${ }^{1} \mathrm{H}$ NMR: $\delta=1.30(\mathrm{dtt}, J(9,9)=8.1, J(1,9$ syn $)=J(4,9 s y n)=1.6$ $J(2,9$ syn $)=J(3,9$ syn $)=0.6 \mathrm{~Hz} ;$ syn-H9), 1.67 (dq, $J(1,9$ anti $)=J(4,9$ anti $)=$ $J(4 \mathrm{a}, 9$ anti $) \approx 2.0 \mathrm{~Hz}$; anti-H9), $2.11(\mathrm{dm} ; \mathrm{H} 4 \mathrm{a}), 2.54$ (dddt, $J(7,7)=20.0$, $J(4 \mathrm{a}, 7$ endo $)=11.0 . J(5,7$ endo $)=3.0, J(6,7$ endo $)=J(7$ endo, 8$)=1.7 \mathrm{~Hz}$; endo $\mathrm{H} 7$ ), 2.70 (dddd, $J(7$ exo,8) $=6.2, J(6,7$ exo $)=5.2, J(4 \mathrm{a}, 7$ exo $)=4.0 \mathrm{~Hz}$; exoH7), 2.81 (br s; H4), 3.34 (br s; H1), 5.71 (dm; H8), 5.85 (br dd, $J(5.6)=9.0$, $J(4 \mathrm{a}, 5)=1.3 \mathrm{~Hz} ; \mathrm{H} 5), 5.88$ (ddddd, $J(4 \mathrm{a}, 6)=3.1, J(6,8)=0.9 \mathrm{~Hz} ; \mathrm{H6}), 6.10$ (br dd, $J(2,3)=5.6, J(1,2)=2.9 \mathrm{~Hz} ; \mathrm{H2}), 6.39$ (br dd, $J(3,4)=3.1 \mathrm{~Hz} ; \mathrm{H3}$ ); ${ }^{3}{ }^{3} \mathrm{C} \mathrm{NMR}: \delta=28.4(\mathrm{t} ; \mathrm{C} 7), 42.6(\mathrm{~d} ; \mathrm{C} 4 \mathrm{a}), 45.2,48.9$ (each d; C1,4), $50.8(\mathrm{t}$; C9), 114.7 (d; C8), 129.7, 131.1, 133.0 (each d; C3,5,6), 139.0 (d; C2), 145.2 (s; C8a)

[a] The assignment is based on decoupling and NOE experiments.

results, ${ }^{[10]}$ we assume that two-step processes occur with diradical intermediates such as 19 and 20 when styrene is used as the trapping reagent. Apparently, the ring closures of 19 and 20 yield 4 and 11, respectively, with high selectivity under kinetic control. These are thermodynamically less stable than their conjugated isomers 5 and 12, respectively.
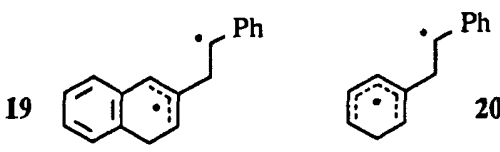

The latter is supported by the thermolyses of 4 and 11, which lead mainly to $5(81 \%)^{[?]}$ and a $1: 3$ mixture $(64 \%)$ of 11 and $12,{ }^{[7]}$ respectively. Here, the diradicals 19 and 20 should again be intermediates, because the ring closures $19 \rightarrow 4$ and $20 \rightarrow 11$ are probably reversible above $100^{\circ} \mathrm{C}$. The preferred pathways of 19 and 20 to the nonconjugated products 4 and 11, respectively, are attributed to the absolute spin density maximum in the benzyl position of the allyl radical moiety of 19 , and in the center of the pentadienyl radical part of $\mathbf{2 0}$, respectively. In the case of $\mathbf{2 0}$, this is the result of a theoretical study, which also describes the nature of the isobenzene 3 (see following communication ${ }^{[1]}$ ).

\section{Experimental Procedure}

11: To a stirred solution of 1,3-cyclopentadiene $(2.25 \mathrm{~g}, 34.0 \mathrm{mmol})$ and tetra bromomethane ( $11.3 \mathrm{~g}, 34.1 \mathrm{mmol})$ in ether $(50 \mathrm{~mL}), \mathrm{MeLi}(34.0 \mathrm{mmol}, 34 \mathrm{~mL}$, $1.0 \mathrm{M}$ in ether) was added dropwise at $-60^{\circ} \mathrm{C}$ under $\mathrm{N}_{2}$ during $1 \mathrm{~h}$. Then the mixture was warmed to $-30^{\circ} \mathrm{C}$, and styrene $(20 \mathrm{~g}, 192 \mathrm{mmol})$ was added. A further $34.0 \mathrm{mmol}$ of $\mathrm{MeLi}$ was then added dropwise over $30 \mathrm{~min}$. The mixture was stirred continually and allowed to warm to $0^{\circ} \mathrm{C}$ over a $4 \mathrm{~h}$ period. Then water $(30 \mathrm{~mL})$ was added and the phases were separated. The aqueous phase was extracted with ether $(3 \times 30 \mathrm{~mL})$. The combined ether layers were dried with $\mathrm{Na}_{2} \mathrm{SO}_{4}$, concentrated at $20^{\circ} \mathrm{C} / 20$ torr, and the excess styrene was distilled off at $20^{\circ} \mathrm{C} / 0.1$ torr. From the residue, colorless $11(3.04 \mathrm{~g}, 49 \%)$ was distilled at $100^{\circ} \mathrm{C}$ (kugelrohr) $/ 0.1$ torr, which probably contained ca. $5 \%$ of its diastereomer.

17 and 18: As described above, to a solution of 1,3-cyclopentadiene (8.0 g, $121 \mathrm{mmol}$ ) and tetrabromomethane $(4.14 \mathrm{~g}, 12.5 \mathrm{mmol})$ in ether $(10 \mathrm{~mL}), \mathrm{MeLi}$ (13.1 mmol and $14.6 \mathrm{mmol}$ ) was added at -60 and $-30^{\circ} \mathrm{C}$, respectively. The final distillation at $60^{\circ} \mathrm{C}$ (kugelrohr) $/ 0.1$ torr yielded a yellowish liquid $(1.56 \mathrm{~g}$ ). Purification by flash chromatography $\left(\mathrm{SiO}_{2}\right.$, pentane) afforded firstly dicyclopentadiene, then $18(145 \mathrm{mg}, 8 \%)$, and finally $307 \mathrm{mg}$ of a $5.7: 1.0$ mixture of $17(14 \%)$ and benzonorbornadiene $(2 \%)$. Pure 17 was obtained by preparative gas chromatography (column length: $1.5 \mathrm{~m}, 20 \%$ ethylene glycol adipate (EGA) on Volaspher ${ }^{\oplus}, 100^{\circ} \mathrm{C}$ ). A mixture of 17 and 18 was dehydrogenated with 2,3-dichloro-5,6-dicyano-p-benzoquinone (DDQ) which yielded benzonorbornadiene ( $38 \%$ )

Received: November 15, 1991 [Z 5024IE] German version: Angew. Chem. 1992, 104, 47 
CAS Registry numbers:

2, 139407-87-7; 3, 124869-33-6; cis-4, 139407-88-8; cis-5, 139407-89-9; 6 $139407-90-2$; cis-7, 139407-91-3; 8, 139407-92-4; 9, 139407-93-5; 10, 139407 94-6; cis-11, 139244-61-4; trans-11, 139408-00-7; 12, 139407-95-7; 13, 139407 $96-8 ; 14,88472-16-6 ; 15,139407-97-9 ;, 16,139407-98-0 ; 17,139407-99-1$ 18, 139492-53-8; $\mathrm{PhCH}=\mathrm{CH}_{2}, 100-42-5 ; \quad \mathrm{H} \mathrm{C}=\mathrm{CHCH}=\mathrm{CH}_{2}, \quad 106-99-0$ $\mathrm{PhCMe}=\mathrm{CH}_{2}$, 98-83-9; (E)-PhCH $=\mathrm{CHMe}, 873-66-5 ; \mathrm{CHBr}_{3}$, 75-25-2; $\mathrm{CHBr}_{2} \mathrm{~F}, 1868-53-7$; $\mathrm{CBr}_{4}$, 558-13-4; indene, 95-13-6; cyclopentadiene, 54292-7; furan, 110-00-9.

[1] B. Miller, X.Shi, J. Am. Chem. Soc. 1987, 109, 578-579.

[2] W. C. Shakespeare, R. P. Johnson, J. Am. Chem. Soc. 1990, 112, 8578 8579 .

[3] M. Christl, M. Braun in Strain and Its Implications in Organic Chemistry (Eds.: A. de Meijere, S. Blechert), Kluwer, Dordrecht, 1989, S. 121-131.

[4] R. P. Johnson, Chem. Rev. 1989, 89, 1111-1124.

[S] W. E. Parham, H. E. Reiff, P. Schwarzentruber, J. Am. Chem. Soc. 1956 $78,1437-1440$.

[6] M. Christl, M. Braun, Chem. Ber. 1989, 122, 1939-1946.

[7] The proposed structures of the new compounds are in agreement with the analytical and spectroscopic data (cf. Table 1). The isolation of the compounds was achieved by kugelrohr distillation at 0.1 torr $(5,8-12,16-18)$, flash chromatography on $\mathrm{SiO}_{2}$ with pentane $(4,7-9,15-18)$ or crystallization (6, from methanol).

[8] N. V. Volchkov, A. V. Zabolotskikh, M. B. Lipkind, and O. M. Nefedov, (Izv. Akad. Nauk SSSR, Ser. Khim 1989, 1935; Chem. Abstr. 1990, 112, $138661 \mathrm{~d}$ ) describe as a result of the $\mathrm{CBrF}$ addition to indene under very similar conditions to those here, not 6 , but 2-fluoronaphthalene which arose from the diastereomer of 6 by rearrangement and subsequent elimination of $\mathrm{HBr}$.

[9] For this method of production of dibromocarbene, see also; W. T. Miller, Jr., C. S. Y. Kim, J. Am. Chem. Soc. 1959, 81, 5008-5009; L. Skattebøl, Tetrahedron Lett. 1961, 167-172.

[10] S. Harnos, S. Tivakornpannarai, E. E. Waali, Tetrahedron Lett. 1986, 27, 3701-3704; M. Christl, M. Schreck, Chem. Ber. 1987, 120, 915-920.

[11] R. Janoschek, Angew. Chem. 1992, 104, 473; Angew'. Chem. Int. Ed. Engl. 1992, 31, 476

\section{1,2,4-Cyclohexatriene, an Isobenzene, and its $[2+2]$ Cycloaddition with Styrene: A Theoretical Study**}

\section{By Rudolf Janoschek*}

Only a fraction of the 217 constitutional isomers with the general formula $\mathrm{C}_{6} \mathrm{H}_{6}$ are known. In the preceding communication Christl et al. describe their successful generation of the isobenzene 1,2,4-cyclohexatriene (1), which was proven by subsequent trapping reactions. ${ }^{[1]}$ The identification of this interesting compound raises a number of questions. Where does isobenzene fit into the series of $\mathrm{C}_{6} \mathrm{H}_{6}$ isomers with regard to its heat of formation? What is its equilibrium geometry? Is this a chiral compound, and if so, how high is the barrier to racemization? What evidence is there for a possible diradical character of 1 ? Questions arise concerning the chemoselectivity in its [2+2] cycloaddition with styrene. The amount of information in the respective answers can be increased by the comparison of this isobenzene with related known compounds, primarily with 1,2-cyclohexadiene (2) which has been investigated experimentally ${ }^{[2]}$ and theoretically. ${ }^{[3]}$

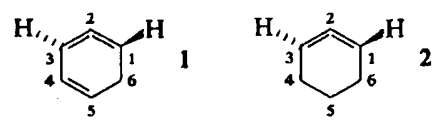

[*] Prof. R. Janoschek

Institut für Theoretische Chemie der Universität Mozartgasse 14, A-8010 Graz (Austria)

[**] I wish to thank Prof. M. Christl, Würzburg for his initiative which sparked this work.
To answer these questions we employed the semiempirical AM1 method. ${ }^{[4]}$ This computational method provides especially reliable results for hydrocarbons; another advantage is the speed with which answers for our list of complicated questions may be obtained. The calculations were conducted with the MOPAC6 program $^{[5]}$ on a STARDENT computer. ${ }^{[6]}$ The bent and twisted allene fragments in 1 and 2 give rise to diradical character which requires a multiconfigurational wave function for its correct description. ${ }^{[7]}$ The calculations were thus carried out with the configuration interaction (CI) formalism, in which all electronic configurations arising from the distribution of two electrons in two orbitals are taken into account. The restricted Hartree-Fock (RHF) open-shell orbitals served in the construction of the configurations. On the energy hypersurfaces numerous stationary points, discussed later in this communication, were characterized either as minima or saddle points (transition structures) by their complete sets of harmonic vibrational frequencies.

The calculated heat of formation of $1,93.7 \mathrm{kcal} \mathrm{mol}^{-1}$, is considerably higher than that of benzene $\left(22.0 \mathrm{kcal} \mathrm{mol}^{-1}\right)$. This increase in energy relative to benzene can be understood as arising from three contributions: loss of the stabilization of benzene, ring strain (bent allene), and rehybridization of the C6 center $\left(\mathrm{sp}^{2} \rightarrow \mathrm{sp}^{3}\right)$. The heat of formation of 1 correlates well with the values of the known $\mathrm{C}_{6} \mathrm{H}_{6}$ isomers like fulvene $\left(62.6 \mathrm{kcalmol}^{-1}\right)$ and Dewar benzene $\left(116.7 \mathrm{kcal} \mathrm{mol}^{-1}\right)$.

A "planar or chiral allene fragment" are the two possible structural alternatives for 1 . Significant calculated structural data are listed in Table 1 . The local energy minimum corre-

Table 1. Structural data for 1 and 2 (bond lengths in $\AA$, angles in degrees), for the energy minima $\left(C_{1}\right.$ and $\left.C_{2}\right)$, and for the transition structures $\left(C_{3}\right)$ of the racemizations.

\begin{tabular}{|c|c|c|c|c|}
\hline & \multicolumn{2}{|c|}{1} & \multicolumn{2}{|c|}{2} \\
\hline & $C_{1}$ & $c$. & $C_{2}$ & $C_{\mathrm{s}}$ \\
\hline $\mathrm{C} 1-\mathrm{C} 2$ & 1.334 & 1.335 & 1.329 & 1.347 \\
\hline $\mathrm{C} 2-\mathrm{C} 3$ & 1.348 & 1.377 & 1.329 & 1.347 \\
\hline C3-C4 & 1.456 & 1.424 & 1.497 & 1.488 \\
\hline $\mathrm{C} 4 \mathrm{CS}$ & 1.354 & 1.364 & 1.538 & 1.526 \\
\hline C5-C6 & 1.502 & 1.486 & 1.538 & 1.526 \\
\hline C1-C6 & 1.493 & 1.488 & 1.497 & 1.488 \\
\hline $\mathrm{C}_{1}-\mathrm{C}_{2}-\mathrm{C}_{3}$ & 132.4 & 131.9 & 133.7 & 133.3 \\
\hline $\mathrm{H}-\mathrm{C} 1-\mathrm{C} 2-\mathrm{C} 3$ & -159.0 & 180.0 & -154.3 & -178.5 \\
\hline $\mathrm{H}-\mathrm{C} 3-\mathrm{C} 2-\mathrm{C} 1$ & -163.1 & 180.0 & -154.3 & 178.5 \\
\hline $\mathrm{C} 5-\mathrm{C} 4-\mathrm{C} 3-\mathrm{C} 2$ & -23.8 & 0.0 & -29.8 & -21.9 \\
\hline $\mathrm{C} 4-\mathrm{C} 3-\mathrm{C} 2-\mathrm{Cl}$ & 12.1 & 0.0 & 21.2 & 0.2 \\
\hline
\end{tabular}

sponds to a chiral structure with $C_{1}$ symmetry. The dihedral angles $\mathrm{H}-\mathrm{C} 1-\mathrm{C} 2-\mathrm{C} 3$ and $\mathrm{H}-\mathrm{C} 3-\mathrm{C} 2-\mathrm{C} 1$ with an average value of $-161^{\circ}$ are characteristic $\left(-180^{\circ}\right.$ corresponds to a planar orientation). The C1-C2-C3 angle of $132.4^{\circ}$ is indicative of considerable ring strain. Optical activity for the calculated chiral structure of 1 can be expected only if the energy barrier (activation enthalpy) to racemization is high enough. The corresponding transition structure has $C_{\mathrm{a}}$ symmetry and is only $2 \mathrm{kcal} \mathrm{mol}^{-1}$ higher in energy than the $C_{1}$ minimum (Fig. 1). The resulting high rate of racemization rules out the observation of optical activity. Isobenzene can thus be designated as dynamically chiral.

The predictive value of the calculated properties of the new compound 1 can be understood better if the related known 1,2-cyclohexadiene (2) is referred to. Significant structural data for both 1 and 2 are provided in Table 1. In the minimum energy structure of $2\left(C_{2}\right.$ symmetry) the expanded dihedral angle $\mathrm{H}-\mathrm{C} 1-\mathrm{C} 2-\mathrm{C} 3\left(-154^{\circ}\right)$ relative to that 